\title{
Application Of Health Protocols In Adaptation New Habits (Case Study Of Sanitarian In Mamuju District, Indonesia)
}

\author{
Agus Erwin Ashari ${ }^{1}$, Fajar Akbar ${ }^{2}$, Fahrul Islam ${ }^{3}$, Ashriady $^{4}$, Abbas Mahmud $^{5}$, Rahmat Haji Saeni ${ }^{6}$ \\ 1,2,3 Department of Environmental Health Poltekkes Ministry of Health Mamuju \\ ${ }^{4,5}$ Department of Midwifery, Health Polytechnic of the Ministry of Health, Mamuju \\ ${ }^{6}$ Department of Nutrition, Health Polytechnic of the Ministry of Health, Mamuju
}

DOI: 10.29322/IJSRP.10.12.2020.p10811

http://dx.doi.org/10.29322/IJSRP.10.12.2020.p10811

\begin{abstract}
Public discipline in enforcing health protocols is the main key in suppressing transmission of COVID-19. The discipline of applying the $3 \mathrm{M}$ health protocol, namely wearing masks, maintaining distance, and washing hands with soap. The purpose of this study was to describe the application of health protocols to sanitarian workers in Mamuju district. This research method is an observational study, with a descriptive design, the sample is a Sanitarian who is assigned to a health service facility in Mamuju District. The sampling method is carried out by accidental sampling of 19 people, information is obtained through a questionnaire on google form which is sent via social media WhatsApp. The results showed that using a mask before boarding a vehicle, always using a mask at work, still using a mask on the way home from work was $100 \%$, carried a spare mask of 17 people $(89.5 \%)$ and who did not bring 2 people $(10.5 \%)$. Only $68.4 \%$ of them used a different mask when they came and came home. The implementation of the health protocol for washing hands with soap / hand sanitizer has $100 \%$ implemented the health protocol, namely going to work with a hand sanitizer. only use a hand sanitizer after handling money, wash your hands with soap and running water as much as possible, use a hand sanitizer after work, wash your hands with soap or hand sanitizer before entering the house. Keep a minimum distance from other people of 1 meter, if using public transportation, if driving using your own helmet, as much as $100 \%$. Keeping a minimum distance from colleagues of 1 meter as much as $84.2 \%$, not shaking hands when meeting colleagues or relations as much as $68.4 \%$. In general, the application of health protocols using masks, washing hands with soap / hand sanitizer, maintaining distance when leaving for work, during work and when returning home by sanitarians is very high.
\end{abstract}

Index Terms- Health protocol, sanitarian, new habits, sanitarian

\section{INTRODUCTION}

$\mathrm{B}$ ehavior is defined as the action or actions of a person related to himself or others. The expected behavior change, especially in compliance with the Covid-19 preventive health protocol, which is often known as $3 \mathrm{M}$, namely wearing masks, maintaining distance and avoiding crowds, and washing hands with soap (BNPB, 2020).

Health protocols are rules and regulations that must be followed by all parties. so that people can continue to carry out activities safely and also not endanger the health of others. (Ministry of Health, 2020) New Normal is a change in behavior to continue carrying out normal activities but by implementing health protocols with the aim of preventing the transmission of Covid-19. Indonesian Ministry of Health, (2020)

Decree of the Minister of Health (KMK) Number HK.01.07 / MENKES / 328/2020 concerning Guidelines for the Prevention and Control of Covid-19 in Office and Industrial Workplaces in supporting business continuity in a pandemic situation as a guide to welcoming a new normal life transition in the world of business and work. (Indonesian Ministry of Health, 2020). The role of the community in being able to break the chain of transmission of COVID-19 (risk of contracting and transmitting) must be done by implementing health protocols. (Ministry of Health, 2020)

Adherence to health protocols can be more effective in preventing transmission if done collectively and not alone. Several international journals state that washing hands with soap can reduce the risk of transmission by $35 \%$. While wearing a cloth mask can reduce the risk of transmission by $45 \%$, wearing a surgical mask can reduce the risk of transmission by $70 \%$. (Maruli Sinambela, 2020)

The use of masks is part of a comprehensive series of preventive and control measures that can limit the spread of certain respiratory viral diseases, including COVID-19 (WHO, 2020). This is in accordance with the results of the study which concluded that the proportion of respondents who experienced ARI is greater for respondents who do not use masks $(77.8 \%$ ) compared to those who use masks $(39.1 \%)$ (Rustika, 2018), There is a relationship between the use of masks and the incidence of ARI (Tri R. Pujiani, 2017), there is an influence between wearing habits. masks with the incidence of ARI. (Hasanah, 2019)

The behavior of maintaining hand hygiene by diligently washing hands and using hand sanitizers will prevent transmission and spread of Covid 19 by hand (Statistics, 
2020a), this is in accordance with the results of research that washing hands with soap that is practiced properly and correctly is the easiest and most effective way to prevent outbreaks of infectious diseases, such as Cholera, Hepatitis A, and ISPA. (Santoso Ujang Effendi, Rina Aprianti, 2019), Antiseptic hand sanitizers are effective in reducing the number of germs (Desiyanto \& Djannah, 2013). Washing your hands using a hand sanitizer reduces the number of germs (Cordita, Raka Novadlu, Soleha, Tri Umiana, Mayasari, 2017). Another thing that was revealed in the study was that the compliance of nurses in washing hands was quite obedient (53.0\%) (Jayu Catur Ruci, Titan Ligita, 2013). Maintaining distance is one of the main regulations in health protocols to prevent transmission of the Covid-19 virus, because maintaining a minimum distance of 1 meter can reduce the risk of transmission by up to $85 \%$. (Majni, 2020)

Sanitarians are a part of health workers who are at the forefront of providing promotive and preventive health services during the Covid-19 pandemic, so they must guard themselves and be protective in working by implementing health protocols, namely wearing masks, washing hands with soap / hand sanitizer, keep your distance and avoid crowds. This study aims to describe the application of health protocols to sanitarian workers in Mamuju district, West Sulawesi Province

his study aims to describe the application of health protocols to sanitarian workers in Mamuju district, West Sulawesi Province

\section{RESEARCH METHODS}

Types of research

The type of research used is observational research, with a descriptive design.

Location and Time of Research

This research is located in Mamuju District, West Sulawesi and was conducted in July - October 2020.

Population and Sample

The population of this research is all sanitarians who work in service facilities health in Mamuju District is people 58 (Dinkes Mamuju, 2020). The sample in this study were sanitarians who served in health care facilities in Mamuju District. The sampling method was carried out by accidental sampling. The number of respondents in this study were 19 respondents.

Data collection

The research data was collected through a questionnaire on google form which was sent via social media WhatsApp to sanitarians in Mamuju District.

Processing and analysis of data

The results of this study are presented in the form of a descriptive table for the health protocol variables.

\section{RESEARCH RESULT}

Table 1. Frequency Distribution according to Respondent Characteristics

\begin{tabular}{|c|c|c|c|}
\hline \multicolumn{2}{|c|}{ Variable } & Frequency & $\%$ \\
\hline \multirow{2}{*}{ Gender } & Male & 4 & 21.1 \\
\hline & Female & 15 & 78.9 \\
\hline & Total & 19 & 100.0 \\
\hline \multirow{3}{*}{$\begin{array}{l}\text { Working } \\
\text { period of }\end{array}$} & 1 - 5 years & 10 & 52.6 \\
\hline & $6-10$ years & 5 & 26.3 \\
\hline & $>10$ years & 4 & 21.1 \\
\hline & Total & 19 & 100.0 \\
\hline \multirow[t]{2}{*}{ education } & Diploma III & 14 & 73.7 \\
\hline & S1/DIV & 5 & 26.3 \\
\hline & Total & 19 & 100.0 \\
\hline \multirow{5}{*}{$\begin{array}{l}\text { Age } \\
\text { (years) }\end{array}$} & $20-25$ & 3 & 15.8 \\
\hline & $26-30$ & 8 & 42.1 \\
\hline & $31-35$ & 4 & 21.1 \\
\hline & $36-40$ & 2 & 10.5 \\
\hline & $>40$ & 2 & 10.5 \\
\hline \multicolumn{2}{|r|}{ Total } & 19 & 100.0 \\
\hline
\end{tabular}

Distribution of respondents in table 1 based on gender illustrates that most of the respondents are female as many as 15 people $(78.9 \%)$ and only 4 men $(21.1 \%)$. Respondents based on education show that education S1 / DIV as many as 5 people $(26.3 \%)$ and Diploma III as many as 14 people $(73.7 \%)$

In table 1 , it can be seen that the respondents based on the working period mostly have a work period of 1-5 years as many as 10 people $(52.6 \%)$ and a working period of more than 5 years as many as 9 people $(47.4 \%)$, while the respondents according to the group 8 people aged $26-30$ years $(42.1 \%)$, followed by the 31- 35 years age group as many as 4 people (21.1\%), 3 people aged $20-25$ years $(15.8 \%)$ and the age group 36 - 40 years and over 40 years respectively as many as 2 people $(10.5 \%)$.

Table 2. Frequency distribution according to the action of using masks 


\begin{tabular}{llcc}
\hline \multicolumn{1}{c}{ Action } & Answer & Total & \% \\
\hline $\begin{array}{l}\text { Use a mask before } \\
\text { getting on a } \\
\text { vehicle }\end{array}$ & Yes & 19 & 100.0 \\
\hline $\begin{array}{l}\text { When you go to } \\
\text { work you bring a } \\
\text { spare mask }\end{array}$ & Yes & 0 & 0.0 \\
\hline $\begin{array}{l}\text { Always wear a } \\
\text { mask at work }\end{array}$ & No & 2 & 89.5 \\
\hline $\begin{array}{l}\text { Keep using a } \\
\text { mask on the way } \\
\text { home from work }\end{array}$ & No & 19 & 10.5 \\
\hline $\begin{array}{l}\text { Use a different } \\
\text { mask when } \\
\text { coming and } \\
\begin{array}{l}\text { coming home } \\
\text { from work }\end{array}\end{array}$ & Yo & 0 & 0.0 \\
\hline
\end{tabular}

Table 2 shows the respondents in implementing the health protocol using masks, it appears that the use of masks before boarding a vehicle is 19 people $(100 \%)$, and carrying spare masks are 17 people $(89.5 \%)$ and those who do not carry as many as 2 people (10.5\%) ). Always use masks at work as many as 19 people (100\%). There were 19 people (100\%) still using masks on their way home from work, 13 people $(68.4 \%)$ using different masks $(68.4 \%)$ and $6(31.6 \%)$ who did not use masks

Table. 3 Frequency Distribution According to the Action of Washing Hands with Soap

\begin{tabular}{llcc}
\hline \multicolumn{1}{c}{ Action } & Answer & Total & \% \\
\hline $\begin{array}{l}\text { When leaving for } \\
\text { work, bring a hand } \\
\text { sanitizer }\end{array}$ & Yes & 18 & 94.7 \\
\hline $\begin{array}{l}\text { if forced to hold } \\
\text { money, do you use } \\
\text { a hand sanitizer } \\
\text { afterwards }\end{array}$ & Yes & 19 & 100.0 \\
\hline $\begin{array}{l}\text { Wash hands } \\
\text { immediately with }\end{array}$ & No & 0 & 0.0 \\
$\begin{array}{l}\text { soap and running } \\
\text { water }\end{array}$ & No & 19 & 100.0 \\
\hline $\begin{array}{l}\text { Use the hand } \\
\text { sanitezer after work }\end{array}$ & Yes & 19 & 100.0 \\
\hline $\begin{array}{l}\text { Washing hands } \\
\text { with soap or hand } \\
\text { sanitizer before } \\
\text { entering the house }\end{array}$ & Yes & 19 & 100.0 \\
\hline
\end{tabular}

From Table 3, the implementation of the health protocol for washing hands with soap shows that 18 people $(94.7 \%)$ brought hand sanitizers to work and only 1 person $(5.3 \%)$ did not carry hand sanitizers, using hand sanitizers after holding 19 cash. 19 people (100\%), washed their hands with soap and running water (100\%), 19 people used a handsanitezer after work $(100 \%), 19$ people washed their hands with soap or hand sanitizer before entering the house (100\%).

Table 4. Frequency distribution according to the act of maintaining distance

\begin{tabular}{llcc}
\hline \multicolumn{1}{c}{ Action } & Answer & Total & \% \\
\hline $\begin{array}{l}\text { If using public } \\
\text { transportation, keep a } \\
\text { minimum distance } \\
\text { from other people of } \\
1 \text { mete }\end{array}$ & Yes & 19 & 100.0 \\
\hline $\begin{array}{l}\text { If driving using your } \\
\text { own helmet }\end{array}$ & Yes & 19 & 100.0 \\
\hline $\begin{array}{l}\text { Try not to frequently } \\
\text { touch shared facilities }\end{array}$ & Yes & 19 & 100.0 \\
/ equipment & No & 0 & 0.0 \\
\hline $\begin{array}{l}\text { Maintain a minimum } \\
\text { distance from } \\
\text { colleagues of } 1 \text { meter }\end{array}$ & Yes & 16 & 84.2 \\
\hline $\begin{array}{l}\text { Shake hands when } \\
\text { meeting colleagues or } \\
\text { relatives }\end{array}$ & Yes & 6 & 15.8 \\
\hline
\end{tabular}

Table 4 illustrates the application of health protocols in terms of keeping a distance showing that keeping a distance from other people at least 1 meter when using public transportation is 19 people (100\%), 19 people $(100 \%)$ use their own helmet, Try not to touch often Facilities / equipment shared by 19 people $(100 \%)$. Maintain a distance from colleagues of at least 1 meter as many as 16 people $(84.2 \%)$ and 3 people $(15.8 \%)$ who do not keep their distance, Shake hands when meeting colleagues or relations as many as 6 people $(31.6 \%)$ and 13 people $(68.4 \%)$ who did not shake hands

\section{DISCUSSION}

Put on a mask

The results showed that the implementation of health protocols on the behavioral aspects of using masks on sanitarians generally complied with the health protocols described in table 2, namely using masks before riding a vehicle as many as 19 people $(100 \%)$, the same thing was revealed that $96.06 \%$ of respondents who using ojol / opang admits that drivers wear masks (Statistics, 2020b), most people $(95.4 \%)$ consider wearing masks when traveling as 
important (Pinasti, 2020), as many as $95.8 \%$ of Wonosobo people have good behavior., form The behaviors shown include obedience in using masks when outside the home (Purnamasari \& Raharyani, 2020), actions on officers using masks when leaving for work, which is high, namely $99.4 \%$ and carrying a spare mask of $89.6 \%$ (Akbar et al. , 2020), $70.3 \%$ of respondents have good skills regarding the prevention of COVID-19, consistency of wearing masks. (Utami et al., 20 20)

The application of other health protocols related to wearing masks in this study is to always use masks at work as many as 19 people (100\%), still use masks on the way home from work as many as 19 people (100\%), indicating that most people obey using masks, namely 46 respondents $(74.19 \%)$ (Devi Pramita Sari \& Nabila Sholihah 'Atiqoh, 2020), That only $23.33 \%$ of people use masks (Siahaineinia \& Bakara, 2020)

Thirteen people $(68.4 \%)$ used different masks when they came and came home from work, and 6 people $(31.6 \%)$ did not use masks. The same thing was concluded in previous research that $70.6 \%$ used different masks when they came and came home from work (Saeni et al., 2020), 94.35\% of respondents admitted that their work environment had applied masks (Statistics, 2020b). This is in line with WHO, which stated that the use of masks is part of a comprehensive series of prevention and control measures that can limit the spread of certain respiratory viral diseases, including COVID-19. Masks can be used either to protect a healthy person (worn to protect oneself in contact with an infected person) or to control sources (worn by an infected person to prevent further transmission). (WHO, 2020).

This study also illustrates that 17 people $(89.5 \%)$ carried spare masks when they went to the office and $2(10.5 \%)$ did not bring along as many as 2 people $(10.5 \%)$. wash and change their masks regularly after being used for traveling during the Corona virus pandemic. (Pinasti, 2020)

Wash your hands with soap / hand sanitizer

The results showed that the application of health protocols in the aspect of health protocols to wash hands with soap illustrated that 18 people $(94.7 \%)$ brought hand sanitizers when leaving for work and only 1 person (5.3\%) did not carry hand sanitizers. A different thing from previous research shows that only $14.2 \%$ of people always carry hand sanitizers when traveling (Pinasti, 2020)

Washing hands with soap and running water as many as 19 people $(100 \%)$, this is in line with what it is said that washing hands is a new behavior and must be done at all times after activities to prevent corona virus transmission. As many as $80.20 \%$ of respondents stated that they often wash their hands for 20 seconds with soap, $82.56 \%$ of respondents admit that their work environment has implemented hand washing / using a hand sanitizer. (Statistics, 2020a); In contrast to other studies, as many as $56.9 \%$ of people have kept their hands clean by washing their hands with soap and running water. (Pinasti, 2020), compliance with washing hands with soap is only $50.46 \%$ (Demsa Simbolon, Darwis, Andra Saferi Wijaya, Hermansyah, Lusi Andriani, Andeka, MoH Gazali, 2020 ), only $26.67 \%$ of respondents wash their hands with soap at Sukaramai Market, Medan North Sumatra (Siahaineinia \& Bakara, 2020)

Using a hand sanitizer after work, hand sanitizer after holding money, is in line with the survey results on the level of compliance of respondents during the past week, especially when outside the house using $77.71 \%$ hand sanitizer / disinfectant, washing hands with soap for 20 seconds as much as $75.38 \%$ and Hand washing in the workplace as much as $82.56 \%$ (Statistics, 2020b). Washing their hands with soap or hand sanitizer before entering the house was 19 people $(100 \%)$, this is in line with a previous study of $96.9 \%$ who washed their hands before entering the house (Saeni et al., 2020)

Keep the distance

From the results of the study, it is illustrated that the application of health protocols in terms of maintaining distance shows that keeping a distance from other people at least 1 meter when using public transportation is 19 people $(100 \%)$, this is different from what $43.15 \%$ of respondents who use public transportation / mikrolet admitted that most of the passengers kept their distance (Statistics, 2020b)

The application of other health protocols in this study illustrates that when driving using their own helmet as many as 19 people $(100 \%)$, this is different from what is depicted that $30.80 \%$ of respondents who use ojol / opang admit that they use their own helmet (Statistics, 2020b).

Maintaining a distance from colleagues of at least 1 meter as many as 16 people $(84.2 \%)$ and 3 people $(15.8 \%)$ who did not keep their distance, the results of the survey on the level of compliance of respondents during the last week kept a minimum distance of 1 meter as much as $73.54 \%$. Avoiding crowds $76.69 \%$ (Statistics, 2020b), $72.62 \%$ of respondents admit that the environment where they work has implemented compulsory distance maintenance (Statistics, 2020a), 11.5\% of the public think that maintaining a minimum distance of 1 meter is not really necessary, even as many as $3.8 \%$ of people think this is not necessary (Pinasti, 2020), good behavior related to social distancing (93.3\%) (Yanti et al., 2020).

In contrast to previous research, $11.5 \%$ of the public were not sure about the application of social distancing or physical distancing, while $0.8 \%$ of the people considered it unnecessary to carry out social distancing or physical distancing during the Corona virus pandemic period (Pinasti, 2020), the proportion of physical behavior good distancing of $55.9 \%$ (Syadidurrahmah et al., 2020), Always, keep 54.29\% distance (Balitbangkes Kemenkes RI, 2020)

Other variables measured in this study were 6 people $(31.6 \%)$ and $13(68.4 \%)$ who did not shake hands when meeting colleagues or relations. This is in line with the conclusion that $81.85 \%$, avoiding handshakes when meeting (Statistics, 2020b)

\section{CONCLUSION}

In this study, it can be concluded that in general the application of health protocols using masks, washing hands with soap / hand sanitizer, maintaining distance when leaving for work, during work and when returning home by sanitarians is very high. 


\section{REFERENCES}

[1] Akbar, F., Islam, F., Ashari, A. E., Mahmud, A., Ashriady, A., \& Saeni, R. H. (2020). Tindakan tenaga kesehatan dalam menerapkan protokol kesehatan saat berangkat kerja pada era kebiasaan baru. Jurnal Kesehatan Manarang, 6 Nomor Khusus, 41-46.

[2] Balitbangkes Kemenkes RI. (2020). Studi Kepatuhan Masyarakat terhadap Himbauan Jaga Jarak dan Perilaku Hidup Bersih selama Pandemi Covid-19. Kemenkes RI, 14-19.

humanitarianresponse.inffo/sites/www.humanitarianres ponse.info/documents/files/paparan_hasil_survey_kepa tuhan_15042020.pdf

[3] BNPB. (2020). Pedoman perubahan perilaku Penanganan Covid-19.

[4] Cordita,Raka Novadlu, Soleha, Tri Umiana , Mayasari, D. (2017). Perbandingan Efektivitas Mencuci Tangan Menggunakan Hand Senitizer dengan Sabun Antiseptik Pada Tenaga Kesehatan di ICU RSUD Dr. H.ABDUL MOELOEK. Agromedicine, 6, 145-153.

[5] Demsa Simbolon, Darwis, Andra Saferi Wijaya, Hermansyah, Lusi Andriani, Andeka, MoH Gazali, Z. M. (2020). Compliance Of The Academic Civities Of The Health Ministry Of Health Bengkulu Following Government Regulations In Prevention Of Covid-19 Virus Transmission.

[6] Desiyanto, F. A., \& Djannah, S. N. (2013). Efektivitas Mencuci Tangan Menggunakan Cairan Pembersih Tangan Antiseptik (Hand Sanitizer) Terhadap Jumlah Angka Kuman. Jurnal Kesehatan Masyarakat (Journal of Public Health), 7(2), 75-82. https://doi.org/10.12928/kesmas.v7i2.1041

[7] Devi Pramita Sari, \& Nabila Sholihah 'Atiqoh. (2020). Hubungan Antara Pengetahuan Masyarakat Dengan Kepatuhan Penggunaan Masker Sebagai Upaya Pencegahan Penyakit Covid-19 Di Ngronggah. Infokes: Jurnal Ilmiah Rekam Medis Dan Informatika Kesehatan, 10(1), 52-55. https://doi.org/10.47701/infokes.v10i1.850

[8] Hasanah, L. (2019). Pengaruh Penggunaan APD Masker dengan Kejadian ISPA pada Pekerja Meubel di Desa Karduluk Tahun 2019. Wiraraja Medika, 9(2), 63-66. https://doi.org/10.24929/fik.v9i2.800

[9] Jayu Catur Ruci, Titan Ligita, A. N. (2013). Gambaran Tingkat Kepatuhan Perawat Akan Cuci Tangan Dalam Terapi Oksigen Dan Tingkat Kejadian Pneumonia Periode Tahun 2012 Dan Tahun 2013 Di Rsud Dr. Rubini Mempawah . Jurnal ProNers, 1(1), 1-4.

[10] Kemenkes, R. I. (2020). Keputusan Menteri Kesehatan Republik Indonesia Nomor Hk.01.07/Menkes/382/2020 Tentangprotokol Kesehatan Bagi Masyarakat Di Tempat Dan Fasilitas Umum Dalam Rangka Pencegahan Dan Pengendalian Corona Virus Disease 2019.

[11] Kementerian Kesehatan RI. (2020). Keputusan menteri kesehatan republik indonesia nomor hk.01.07/menkes/328/2020 tentang panduan pencegahan dan pengendalian. 2019.

[12] Majni, F. A. (2020). Perilaku Disiplin 3M Kunci Utama
Menekan Penularan Covid-19. Media Indonesia. https://mediaindonesia.com/read/detail/349586perilaku-disiplin-3m-kunci-utama-menekan-penularancovid-19

[13] Maruli Sinambela. (2020). Seberapa Efektif Penerapan 3M Menurut Jurnal Internasional? Vibiz Media Network.

https://www.vibizmedia.com/2020/10/01/seberapaefektif-penerapan-3m-menurut-jurnal-internasional/

[14] Pinasti, F. D. A. (2020). Analisis Dampak Pandemi Corona Virus Terhadap Tingkat Kesadaran Masyarakat dalam Penerapan Protokol Kesehatan. Wellness And Healthy Magazine, 2(2), 237-249. https://doi.org/10.30604/well.022.82000107

[15] Purnamasari, I., \& Raharyani, A. E. (2020). Tingkat Pengetahuan dan Perilaku Masyarakat Kabupaten Wonosobo Tentang Covid-19. Jurnal Ilmiah Kesehatan, Mei, 33-42. https://ojs.unsiq.ac.id/index.php/jik/article/view/1311/7 83

[16] Rustika, E. B. (2018). Masker Dalam Upaya Pencegahan Ispa Pada Jemaah Haji Indonesia Di Arab Saudi Tahun 2016. Buletin Penelitian Sistem Kesehatan, 21(3), 180-188.

[17] Saeni, R. H., Ashari, A. E., Akbar, F., Islam, F., Ashriady, A., \& Mahmud, A. (2020). Knowledge, Attitude and Practice of Health Workers against COVID-19 Infection When Returning from Work, Maтијu District , Indonesia ,. 9(11), 223-227. https://doi.org/10.21275/SR201102082755

[18] Santoso Ujang Effendi, Rina Aprianti, S. F. (2019). Faktor-Faktor Yang Berhubungan Dengan Perilaku Mencuci Tangan Menggunakan Sabun Pada Siswa Di SD Negeri 08 Lubuk Linggau. JNPH, 7(2), 62-71.

[19] Siahaineinia, H. E., \& Bakara, T. L. (2020). Persepsi Masyarakat Tentang Penggunaan Masker Dan Cuci Tangan Selama Pandemi Covid-19 Di Pasar Sukaramai Medan. ... Dan Pengabdian Masyarakat UISU, 9(1). https://jurnal.uisu.ac.id/index.php/wahana/article/view/ 2874

[20] Statistik, B. P. (2020a). Hasil Survey Sosial Demografi Dampak Covid-19.

[21] Statistik, B. P. (2020b). Perilaku Masyarakat Di Masa Pandemi Covid-19 (Issue September).

[22] Syadidurrahmah, F., Muntahaya, F., Islamiyah, S. Z., \& Fitriani, T. A. (2020). Perilaku physical distancing mahasiswa UIN Syarif Hidayatullah Jakarta pada masa pandemi covid-19. Jurnal Perilaku Dan Promosi Kesehatan, 2(1), 29-37.

[23] Tri R. Pujiani, A. S. (2017). Hubungan Penggunaan Apd Masker, Kebiasaan Merokok Dan Volume Kertas Bekas Dengan ISPA. Unnes Journal of Public Health, 3(1), 184-188.

[24] Utami, R. A., Mose, R. E., \& Martini, M. (2020). Pengetahuan, Sikap dan Keterampilan Masyarakat dalam Pencegahan COVID-19 di DKI Jakarta. Jurnal Kesehatan Holistic, 4(2), 68-77. https://doi.org/10.33377/jkh.v4i2.85

[25] WHO. (2020). Anjuran mengenai penggunaan masker dalam konteks COVID-19. World Health Organization, 


\section{April, 1-17.}

[26] Yanti, B., Wahyudi, E., Wahiduddin, W., Novika, R. G. H., Arina, Y. M. D., Martani, N. S., \& Nawan, N. (2020). Community Knowledge, Attitudes, and Behavior Towards Social Distancing Policy As Prevention Transmission of Covid-19 in Indonesia. Jurnal Administrasi Kesehatan Indonesia, 8(2), 4. https://doi.org/10.20473/jaki.v8i2.2020.4-14

\section{AUTHORS}

First Author - Agus Erwin Ashari, Department of Environmental Health Poltekkes Ministry of Health Mamuju, Indonesia, agus.rpjmn@gmail.com

Second Author - Fajar Akbar, Department of Environmental Health Poltekkes Ministry of Health Mamuju, Indonesia, fajarpoltekkes@gmail.com

Third Author - Fahrul Islam, Department of Environmental Health Poltekkes Ministry of Health Mamuju, Indonesia, email address, fahrulhasanuddin@gmail.com

Fourth Author - Ashriady, Department of Midwifery, Health Polytechnic of the Ministry of Health, Mamuju, Indonesia, ashriady.abumuadz@gmail.com

Fifth Author - Abbas Mahmud, Department of Midwifery, Health Polytechnic of the Ministry of Health, Mamuju, Indonesia, abbas.mahmud11@gmail.com

Sixth Author - Rahmat Haji Saeni, Department of Nutrition, Health Polytechnic of the Ministry of Health, Mamuju, Indonesia

Correspondence Author - Rahmat Haji Saeni, rahmathajisaeni@gmail.com,081355346080. 